\title{
A Comparative Analysis of Rock Fragmentation using Blast Prediction Results*
}

\author{
${ }^{1}$ G. Agyei and ${ }^{1} \mathrm{M}$. Owusu-Tweneboah \\ ${ }^{1}$ University of Mines and Technology, Tarkwa, Ghana
}

Agyei, G. and Owusu-Tweneboah, M. (2019), "A Comparative Analysis of Rock Fragmentation using Blast Prediction Results”, Ghana Mining Journal, Vol. 19, No. 1, pp. 49 - 58.

\begin{abstract}
This work presents prediction and optimisation of controllable parameters of drilling and blasting currently used at the Fobinso Pit of Perseus Mining Ghana Limited (PMGL). The mine faces challenges with blast particle sizes produced after primary blasting. The presence of boulders requires secondary fragmentation to further reduce the broken materials to the acceptable sizes, thereby increasing the cost of production. The mechanical properties of the rocks were determined using Protodyakonov Rock Strength Index. The drill and blast parameters were estimated using the Konya and Walter (1990), Principle of Proportionality, and Instituto Geologo Minero de España (IGME) model developed in 1987. The Modified KuzRam model was used to predict and analyse the results of blasting based on the parameters such as spacing, burden, drillhole diameter, charge density, charge per hole, charge length, and powder factor. A comparative analysis of the predicted size distributions of the various models using diameters of $65 \mathrm{~mm}$ and $110 \mathrm{~mm}$ revealed no significant differences between the size fractions. The Principle of Proportionality produced the best technical and economic indices for blasting.
\end{abstract}

Keywords: Fragmentation, Drilling Parameters, Primary Blasting, Models, Secondary Blasting

\section{Introduction}

Perseus Mining Ghana Limited (PMGL) is a surface gold mine located at Ayamfuri in the Central Region of Ghana. The mine is currently operating four pits: Fobinso, Fetish, Esuajah North and Chirewewa. The mine has been facing challenges with fragmentation sizes where boulders are frequently produced after the primary blasting. The presence of lump sizes above $300 \mathrm{~mm}$ then requires secondary fragmentation to further reduce the broken materials to the required size where $80 \%$ of the fragmented materials fall below 300 $\mathrm{mm}$ before they are delivered to the processing plant for crushing. Delays and inefficiencies in the blasting activity greatly affect downstream operations such as loading, hauling and crushing. There is therefore the need to review the controllable factors to determine the optimal drill and blast parameters.

The following are some of the vital parameters which determine blast design (Mishra, 2009): pit geometry, explosive characteristics, burden distance, spacing between drillhole, ratio of spacing to burden, hole depth, diameter of drillholes, consideration of toe and depth of subgrade drilling, blasting technique, powder factor, length of stemming column, and quality of stemming.

Issues generally discussed under explosive characteristics are type of explosive, type of booster, bulk strength, energy release per unit mass of explosive, detonation pressure, explosion pressure, ratio of decoupling, strength of explosive, time taken for explosive wave to travel to the free face and back, volume of gases produced per unit mass of the explosive, velocity of detonation and velocity of explosion propagation. The burden is considered the most important and critical value in the design of a surface blast. There are two types of burden; drilled burden and short burden (Mensah, 2012). The drilled burden can be defined as the distance between the rows of holes and the nearest free face measured perpendicular to the row of holes. It is also the distance between two rows of holes. The short burden is defined as the distance between the holes that are detonating and the nearest free face developed during the blast. According to Bhandari (1997), with multiple row blast, the burden may not necessarily be given as the distance to the nearest free face because as the drillholes with the lowest delays detonate, they too create new free faces. As a result, the effective burden will depend on the selection of the delay pattern. Burden values below the optimum would result in an excessive forward throw, high air blast levels, and excessively fine fragmentation. Burden above optimum values would probably yield inadequate fragmentation with possible upward throw causing fly rocks. Excessive burden also causes over confinement of the drillholes, which results in high levels of ground vibrations per mass of explosives used (Hagan, 1983; Konya and Walter, 1990).

Spacing is the distance between adjacent drillholes, measured perpendicular to the burden which controls the mutual effect between holes (Bhandari, 1997). It is calculated as a function of the burden, drillhole depth, and relative primer location between adjacent charges; and also depends upon initiation time interval. According to Frimpong- 
Mensah (2016), smaller spacing distance causes crushing and cratering between holes, large blocks in the burden and toe problems. On the other hand, spacing above the optimum dimensions would result in loss of interaction between detonating charges, while spacing below the optimum values could cause partial cancellations of explosive forces and contribute to excessive vibration. When drillholes are too close, cracks from the closely spaced drillholes will link prematurely causing a shattered zone in the wall between holes. The premature linking of the radial cracks will form a fracture plane between holes through which gases can escape prematurely to the atmosphere causing air blast, flying rocks, and toes. If the drillholes are too far apart, fragmentation will be coarse, and toes, non-uniform and rough walls will result.

Spacing is a function of burden. For most situations, the spacing to burden ratio is between 1 and 2. In general, a ratio of 1:4 is used as an ideal geometric balance for breakage of massive material (Hagan,1983; Mishra, 2009).

According to Bhandari (1997), the drillhole depth depends on the type of rock to be blasted. In a rock material of low strength which is readily loosened, shallow drillholes and smaller explosive charges are generally used. It is important that the burden and the drillhole be reasonably compatible. As a rule of thumb, for bench blasting the drillhole depth to burden ratio should be between 1.4 and 4.0. Hole depths less than 1.5 times the burden cause excessive air blast and fly rocks, course and uneven fragmentation (Hagan, 1983).

According to Konya and Walter (1990), subdrilling is the depth to which drillhole will be drilled below the proposed grade to ensure that breakage will occur to the grade line. This is because drillholes usually do not break to full depth. The sub-drill depends on the burden, orientation of the drillhole relative to all open faces, and the geological structure conditions at its bottom (Hagan, 1983; Bhandari, 1997). If a shear plane or a parting exist at that location, sub-drilling may not be required. As a general rule, the sub-drill length should be equal to about one-third the burden distance for hard ground conditions (Bhandari, 1997). In multiple bench operations, excessive sub-drilling may cause undue fracturing and gouged pit floors, creating difficulties in collaring holes in the lower bench (FrimpongMensah, 2016). The required sub-drilling is also expressed regarding the blast drillhole diameter (Bhandari, 1997). If sub-drilling is required, it is important to limit it to only the minimum length required since excessive sub-drilling may cause floor damage in benching operations (Bhandari, 1997).
The drillhole diameter selected in combination with appropriate positioning of the holes, will give fragmentation suitable for loading, transportation and crushing (Bhandari, 1997). Additional factors to be considered in the determination of the drillhole diameter are the size of operation, the bench height, the type of explosive used and rock characteristics. Occasionally it may be necessary to use two different drillhole sizes within the same blast. According to Olofsson (1988), the borehole diameter dictates the charge diameter and controls the number of explosives in the borehole for any explosive type. It also affects the reaction velocity and thus the detonation pressure.

Powder factor is the ratio between the total weights of the explosives detonated in a blast divided by the amount of rock that is broken (Olofsson, 1988). It is an essential parameter in blast design and has a vital influence on the resultant fragmentation. According to Olofsson (1988), the powder factor is a function of the explosive type, rock density and the geology of the formation being blasted. Competent rock or formation with few or no pronounced planes of weakness require higher powder factor than a formation with numerous closely spaced structural weakness. Stemming is the filling of some part of the blasthole with inert materials such as debris from drilling sand, chipping, tailings from treatment plants and mills (Bhandari, 1997; Olofsson, 1988). Optimum stemming columns with course angular crushed rocks interlock themselves to confine high gas pressure in the blastholes for longer periods permitting the charges to perform to their maximum potential. Stemming below the optimum values can reduce fragmentation and loosening as energy is ejected prematurely to the atmosphere. Optimum stemming increases with a decrease in the effective strength of the rock. Columns below the optimum values cause airblast, cut-offs and overbreak problems (Hagan, 1983). According to Konya and Walter (1990), a stemming height of 0.7 times the burden is adequate to keep material from ejecting prematurely from the hole. Stemming height is proportional to the burden. The optimum size of stemming material would be material that has an average diameter of approximately 0.05 times the diameter of the drillhole.

Protodyakonov rock classification table (Table 1) using the sturdiness index, $f$ values, based on which the rocks were divided into ten (10) categories is shown in Table 1. The Relative Rock Sturdiness Index (f), is suitable for an elaborate and a systemic study of standard machine productivity, and work efficiency for economic analysis of rock fragmentation. The $f$-index is proportional to the 
limit of compressive strength $\left(\sigma_{c}\right)$ of rock as expressed in Equation 1.

The first category refers to rocks with the highest compressive strength and tenth category refers to weak rocks. Protodyakonov used regular samples of $100 \mathrm{kgf} / \mathrm{cm}^{3}$ in designing the table.

$$
f=\frac{\sigma_{c}}{100}
$$

However, field empirical tests have proven that calculation based on the Equation 2 gives a more accurate result.

$$
f=\frac{\sigma_{c}}{300}+\sqrt{\frac{\sigma_{c}}{30}}
$$

In reality, the UCS of some rocks are higher than $2000 \mathrm{kgf} / \mathrm{cm}^{3}$. However, precise results can be obtained when $f=20$ is assumed for high strength rocks. Soft rocks with values below $200 \mathrm{kgf} / \mathrm{cm}^{3}$ should be adjusted to $f=3$.

There is the need to determine the optimum drill and blast parameters to reduce the boulders. The objective of this paper is to do a comparative analysis of Konya and Walter (1990), IGME, and the Principle of Proportionality to predict the blast design parameters for the Fobinso pit of PGML to achieve mean fragment sizes that will help reduce boulders and produce uniform distribution after an initial blast.

\begin{tabular}{|c|c|c|c|c|}
\hline Group & Sturdiness & Description of rock & $f$ & $\begin{array}{l}\text { Powder } \\
\text { factor }\end{array}$ \\
\hline I & Sturdiest & The hardest, toughest and most dense quartzites and basalts. & 20 & $0.7-0.75$ \\
\hline II & Very sturdy & $\begin{array}{l}\text { Very sturdy granite rock, quartz porphyry, siliceous schist, } \\
\text { weaker quartzites } \\
\text { Sturdiest sandstone and limestone. }\end{array}$ & 15 & $0.50-0.70$ \\
\hline III & Sturdy & $\begin{array}{l}\text { Granite (dense) and granite rock. Very sturdy sandstone and } \\
\text { limestones. Quartz veins. } \\
\text { Sturdy conglomerate, very sturdy iron ore. }\end{array}$ & 10 & $0.45-0.60$ \\
\hline IIIa & Sturdy & $\begin{array}{l}\text { Limestones (sturdy), weaker granites } \\
\text { Sturdy sandstones, marble, dolomites and pyrites. }\end{array}$ & 8 & \\
\hline IV & $\begin{array}{l}\text { Rather } \\
\text { sturdy }\end{array}$ & Ordinary sandstones, iron ore. & 6 & $0.45-0.60$ \\
\hline IVa & $\begin{array}{l}\text { Rather } \\
\text { sturdy }\end{array}$ & Sandy schists, schistose sandstones. & 5 & \\
\hline $\mathrm{V}$ & Moderate & $\begin{array}{l}\text { Sturdy shale. Non-sturdy sandstones and limestones } \\
\text { Soft conglomerates. }\end{array}$ & 4 & $0.40-0.50$ \\
\hline $\mathrm{Va}$ & Moderate & Various schists (non-sturdy). Dense marl. & 3 & \\
\hline VI & Rather soft & $\begin{array}{l}\text { Soft schists. Very soft limestones, chalk, rock salt, gypsum, } \\
\text { Frozen soil, anthracite. Ordinary marl. Weathered schists, } \\
\text { compressed shingle and gravel, rocky soil. }\end{array}$ & 2 & $0.35-0.60$ \\
\hline VIa & Rather soft & $\begin{array}{l}\text { Detritus soil. Weathered schists, compressed shingle and detritus, } \\
\text { sturdy bituminous coal, hardened clay. }\end{array}$ & 1.5 & \\
\hline VII & Soft & Clay (dense), soft bituminous coal, sturdy alluvium, clayey soil. & 1.0 & $0.35-0.45$ \\
\hline VIIa & Soft & Soft sandy clay, loess gravel. & 0.8 & $0.30-0.45$ \\
\hline VIII & Earthly & Vegetable earth, peat, soft loam, damp soil. & 0.6 & $0.35-0.40$ \\
\hline IX & $\begin{array}{l}\text { Dry loose } \\
\text { rock }\end{array}$ & $\begin{array}{l}\text { Sand, talus, soft gravel, piled-up earth, and substances extracted, } \\
\text { coal. }\end{array}$ & 0.5 & \\
\hline $\mathrm{X}$ & $\begin{array}{l}\text { Flowing } \\
\text { rock }\end{array}$ & $\begin{array}{l}\text { Shifting sands, swampy soil, rare-fractioned loess, and other rare- } \\
\text { fractioned soils. }\end{array}$ & 0.3 & \\
\hline
\end{tabular}

Table 1 Protodyakonov's Classification of Rock Sturdiness and Powder Factor

\section{Resources and Methods Used}


The following methods were adopted to fulfil the stated objective:

i. Core specimens from many points were collected and carefully packed and sent to the Geotechnical Laboratory of PMGL for the analysis.

ii. After the sample collection, they were prepared for laboratory testing. The collected samples were taken through analysis to know about the Uniaxial Compressive Strength (UCS) to identify the type of rock present using the Protodyakonov's classification of rock sturdiness.

iii. The Determination of UCS was done with HZ-1009G 60T Computer Servo Compression Testing Machine with the following technical working conditions: Maximum Load Capacity: 1200kN; Platens Diameter: $80 \mathrm{~mm}$; Platens Hardness $\geq 58$ HRC; Vertical Clearance: $167 \mathrm{~mm}$; and Overall Dimensions: 249 diameter $\times 333$ mm heights and Weight: $30 \mathrm{~kg}$.

The rock test was compliant with ASTM D 7012 for Rock Core Specimen Test Methods. Field visits for data collection on drill and blast parameters from the mine were conducted. For the calculation of drill parameters, several methods exist. However, for this work, Konya and Walter (1990), Principle of Proportionality, IGME and Fragmentation Size Prediction, using Modified Kuz-Ram, were selected because of their relative simplicity and effectiveness.

The blastability of rocks was determined using Protodyakonov Relative Rock Sturdiness Index, (f).

\subsection{The Principle of Proportionality}

The Principle of Proportionality as a blast design model depends essentially on the drillhole diameter and the rock strength index without taking into account other features like fillings, openings, spacing and orientation of discontinuities. For this reason, the Principle of Proportionality produces precise results if the correct drillhole diameter is selected.

The burden (B) was obtained using Equation 3 (Otaño 1998):

$$
B=D \sqrt{\frac{8.2 \Delta}{m q}}
$$

where $D$ is the diameter of drillhole $(\mathrm{dcm}), \Delta$ is the charge density $\left(\mathrm{dcm}^{3}\right), m$ is the coefficient of approximation of charges, taken between 1.1 and $1.5, q$ is the powder factor, $\mathrm{kg} / \mathrm{m}^{3}$.

Table 2 shows the mathematical expressions and the values of the rest of the controllable parameters by the principle of proportionality.

\subsection{The Konya Method and Walter Method}

The Konya and Walter (1990) Model parameters are burden, spacing, stemming and subdrill. The burden (B) was obtained using Equation 4 as follows:

$$
B=0.012 \times\left[\frac{2 \times \rho_{e}}{\rho_{r}}+1.5\right] \times D
$$

where $\rho_{e}$ is the explosive density $\left(\mathrm{g} / \mathrm{cm}^{3}\right), \rho_{r}$ is the rock density $\left(\mathrm{g} / \mathrm{cm}^{3}\right)$ and $D$ is the drillhole diameter (mm)

The Konya and Walter Method uses bedding and other qualitative characteristics that may bring about unpredictable errors. The parameters using Konya and Walter (1990) model is shown in Table 3.

\subsection{IGME Method}

Like Konya and Walters (1990), the fundamental drill and blast parameters estimated with the IGME method are burden, spacing and subdrill. The method determines the controllable parameters on the basis of the UCS (MPa) of the rock and the proposed diameter of drillhole diameter (D) is expressed in Table 4.

\subsection{Modified Kuz-Ram Model}

The modified form of the Kuz-Ram model with some modification to the Kuznetzov (1973) equation and the uniformity index was used. The Rosin-Rammler function is maintained as in the original Kuz-Ram model. Cunningham (2005) adjusted the Kuz-Ram model. The major changes to the model however, were developed as a result of the introduction of electronic delay detonators (EDs), since these have transformed fragmentation. The new equation, Equation 5 set includes changes in the uniformity and mean fragment size equations as follows:

$$
R_{x}=\exp \left[-0.693\left(\frac{x}{x_{m}}\right)^{n}\right]
$$

Table 2 Drill and Blast Parameters for Principle of Proportionality 


\begin{tabular}{|l|c|c|}
\hline \multicolumn{1}{|c|}{ Parameter } & Symbol & Formula \\
\hline Burden, $\mathrm{m}$ & $\mathrm{B}$ & Equation $(3)$ \\
\hline Spacing, $\mathrm{m}$ & $\mathrm{S}$ & $\mathrm{mB}$ \\
\hline Hole Depth, $\mathrm{m}$ & $\mathrm{H}_{\mathrm{d}}$ & $0.3 B$ \\
\hline Sub-drill, $\mathrm{m}$ & $\mathrm{J}$ & $20 D$ \\
\hline Stemming, $\mathrm{m}$ & $\mathrm{T}$ & Deduced \\
\hline Hole Diameter, $\mathrm{mm}$ & $\mathrm{D}$ & Field Data \\
\hline Bench Height, $\mathrm{m}$ & $\mathrm{H}$ & $(H+0.3 D)-18 D$ \\
\hline Charge Length, $\mathrm{m}$ & $\mathrm{L}_{\mathrm{c}}$ & 1.2 \\
\hline Charge Density, $\mathrm{g} / \mathrm{cc}$ & $\Delta$ & $0.7 \times \mathrm{q} \times \mathrm{S} \times \mathrm{B} \times \mathrm{H}$ \\
\hline Charge Per Hole, $\mathrm{kg}$ & $\mathrm{Q}$ & deduced \\
\hline Powder Factor, $\mathrm{kg} / \mathrm{m}^{3}$ & $\mathrm{q}$ & $\mathrm{S} / \mathrm{B}$ \\
\hline Spacing to Burden Ratio & $\mathrm{S}_{\mathrm{B}}$ & $\mathrm{H} / \mathrm{B}$ \\
\hline Stiffness Ratio & $\mathrm{S}_{\mathrm{R}}$ & Field data \\
\hline Bench width $(\mathrm{m})$ & $\mathrm{B}_{\mathrm{w}}$ & $\frac{B_{w}}{\mathrm{~s}}+1$ \\
\hline Number of rows & $\mathrm{N}_{\mathrm{R}}$ & $B(1-0.1 H)$ \\
\hline Distance between rows $(\mathrm{m})$ & $\mathrm{D}_{\mathrm{R}}$ & \\
\hline
\end{tabular}

Table 3 Drill and Blast Parameters for Konya and Walter (1990)

\begin{tabular}{|c|c|c|}
\hline Designed Parameters & Symbol & Formula \\
\hline Burden (m) & B & Formula \\
\hline Spacing $(\mathrm{m})$ & $\mathrm{S}$ & $\mathrm{S}=[\mathrm{H}+(7 \times \mathrm{B})] / 8$ \\
\hline Hole Depth (m) & $\mathrm{H}_{\mathrm{d}}$, & $\mathrm{H}_{\mathrm{d}}=\mathrm{H}+\mathrm{J}$ \\
\hline Sub-drill (m) & $\mathrm{J}$ & $\mathrm{J}=0.3 \times \mathrm{B}$ \\
\hline Stemming $(\mathrm{m})$ & $\mathrm{T}$ & $\mathrm{T}=0.7 \times \mathrm{B}$ \\
\hline Hole Diameter $(\mathrm{mm})$ & $\mathrm{D}$ & Deduced \\
\hline Bench Height (m) & $\mathrm{H}$ & Field data \\
\hline Charge Length (m) & $\mathrm{L}_{\mathrm{c}}$ & $\mathrm{L}_{\mathrm{c}}=\mathrm{H}_{\mathrm{d}}-\mathrm{T}$ \\
\hline Charge Density $\left(\mathrm{g} / \mathrm{cm}^{3}\right)$ & $\Delta$ & 1.2 \\
\hline Charge Per Hole (kg) & Q & $\mathrm{Q}=\pi \times \mathrm{D}^{2} / 4000 \times \mathrm{L}_{\mathrm{c}} \times \rho_{\mathrm{e}}$ \\
\hline Powder Factor $\left(\mathrm{kg} / \mathrm{m}^{3}\right)$ & $\mathrm{q}$ & $\mathrm{PF}=\frac{\mathrm{Q}}{\mathrm{B} \times \mathrm{S} \times \mathrm{H}_{\mathrm{d}}}$ \\
\hline Spacing Burden Ratio & SB & $S_{B}=\frac{\text { Spacing }}{\text { Burden }}$ \\
\hline Bench Width (m) & $\mathrm{B}_{\mathrm{w}}$ & Field data \\
\hline Stiffness ratio & $\mathrm{S}_{\mathrm{R}}$ & $\mathrm{S}_{\mathrm{R}}=\frac{\text { Bench height }}{\text { Burden }}$ \\
\hline Number of rows & $\mathrm{N}_{\mathrm{R}}$ & $\frac{B_{w}}{S}+1$ \\
\hline Distance Between rows & $\mathrm{D}_{\mathrm{R}}$ & $\mathrm{B}(1-0.1 \mathrm{H})$ \\
\hline
\end{tabular}

Table 4 Relationship between Drill and Blast Parameters and Diameter (IGME, 1987)

\begin{tabular}{|l|c|c|c|c|}
\hline \multicolumn{1}{|c|}{ Parameter } & $\begin{array}{c}\text { Weak } \\
\mathbf{4 7 0}\end{array}$ & $\begin{array}{c}\text { Medium } \\
\mathbf{7 0 - 1 2 0}\end{array}$ & $\begin{array}{c}\text { Hard } \\
\mathbf{1 2 0 - 1 8 0}\end{array}$ & $\begin{array}{c}\text { Very Hard } \\
>\mathbf{1 8 0}\end{array}$ \\
\hline Burden $(\mathrm{mm})$ & 39D & $37 \mathrm{D}$ & $35 \mathrm{D}$ & $33 \mathrm{D}$ \\
\hline Spacing $(\mathrm{mm})$ & 51D & 47D & $43 \mathrm{D}$ & $38 \mathrm{D}$ \\
\hline Stemming $(\mathrm{mm})$ & 35D & $34 \mathrm{D}$ & $32 \mathrm{D}$ & $30 \mathrm{D}$ \\
\hline Sub-drill $(\mathrm{mm})$ & 10D & $11 \mathrm{D}$ & $12 \mathrm{D}$ & $12 \mathrm{D}$ \\
\hline
\end{tabular}


where $R_{x}$ is the mass fraction retained on screen opening $x, x_{m}$ is the mean size and $n$ is the uniformity index.

The mean size, $x_{m}$ is given in Equation 6 as:

$$
x_{m}=A A_{T} K^{-0.8} Q^{1 / 6}\left(\frac{115}{R W S}\right)^{19 / 30} C(A)
$$

where $A$ is rock factor; $K$ is powder factor $\left(\mathrm{kg} / \mathrm{m}^{3}\right)$; $Q$ is mass of explosive in hole $(\mathrm{kg}), R W S$ is weight strength relative to ANFO, 115 is $R W S$ of TNT; $C(A)$ is rock correction factor; and $A_{T}$ is timing factor.

The uniformity index (n) is also given in Equation 7 as:

$$
\begin{aligned}
n= & n_{s} \times \sqrt{\left(2-\frac{30 B}{d}\right)} \times \sqrt{\frac{1+S / B}{2}} \times\left(1-\frac{W}{B}\right) \\
& \times\left(\frac{L}{H}\right)^{0.3} \times C(n) \times\left(\frac{A}{6}\right)^{0.3} \times g
\end{aligned}
$$

where $B$ is burden (m), $S$ is spacing (m), $d$ is hole diameter $(\mathrm{mm}), W$ is standard deviation of drilling precision $(\mathrm{m}), L$ is charge length $(\mathrm{m}), H$ is bench height $(\mathrm{m}), n_{s}$ is timing scatter factor; $C(n)$ is correction factor for known uniformity, $A$ is rock hardness factor, $g$ is geometry factor (MirekuGyimah and Sarpong, 2018) uses Modified KuzRam Model to estimate and compare the fragmentation of two blast designs to determine the optimum sizes and cost.

\section{Results and Discussion}

The Principle of Proportionality and IGME are essentially based on the diameter of drill and the strength of the rocks without considering other important aspects like infill material, discontinuities, joint spacing, and joint orientation. However, they are considered to be more precise than Konya provided the right diameter is selected because they have limited variables in their calculation. The simplest of the three is IGME, model which is based solely on the diameter of drill. The existing drill and blast parameters of PMGL are found in Table 5. The spacing to burden and the stiffness ratios are between 1 and 2. There is a good geometric balance for PGML pit at Fobinso.

From Table 6, the fresh granite is relatively stronger than the fresh phyllite and fresh greywacke rocks. All the rock types can be classified as strong and require an efficient drill and blast design.

Table 5 Designed Drill and Blast Parameters from PMGL at Fobinso Pit

\begin{tabular}{|l|c|c|}
\hline Designed Parameters & Symbol & Values \\
\hline Burden $(\mathrm{m})$ & $\mathrm{B}$ & 3.1 \\
\hline Spacing $(\mathrm{m})$ & $\mathrm{S}$ & 3.5 \\
\hline Hole Depth $(\mathrm{m})$ & $\mathrm{H}_{\mathrm{d}}$ & 6.0 \\
\hline Sub-drill $(\mathrm{m})$ & $\mathrm{J}$ & 1.0 \\
\hline Stemming $(\mathrm{m})$ & $\mathrm{T}$ & 2.6 \\
\hline Hole Diameter $(\mathrm{mm})$ & $\mathrm{D}$ & 115.0 \\
\hline Bench Height $(\mathrm{m})$ & $\mathrm{H}$ & 5.0 \\
\hline Charge Length $(\mathrm{m})$ & $\mathrm{L}_{\mathrm{c}}$ & 3.4 \\
\hline Charge Density $\left(\mathrm{g} / \mathrm{c}^{3}\right)$ & $\Delta$ & 1.2 \\
\hline Charge Per Hole $(\mathrm{kg})$ & $\mathrm{Q}$ & 38.7 \\
\hline Powder Factor $\left(\mathrm{kg} / \mathrm{m}^{3}\right)$ & $\mathrm{q}$ & 0.59 \\
\hline Spacing to Burden Ratio & $\mathrm{S}_{\mathrm{B}}$ & 1.12 \\
\hline Stiffness Ratio & $\mathrm{S}_{\mathrm{R}}$ & 1.61 \\
\hline
\end{tabular}


Table 6 Intact Rock Strength Tests from UCS Testing

\begin{tabular}{|l|c|c|c|}
\hline \multicolumn{1}{|c|}{ Rock Types } & Fresh Granite & Fresh Greywacke & Fresh Phyllite \\
\hline No. of samples & 25 & 12 & 15 \\
\hline Max $(\mathrm{MPa})$ & 330 & 232 & 200 \\
\hline Min $(\mathrm{MPa})$ & 86 & 48 & 46 \\
\hline Range $(\mathrm{MPa})$ & 243 & 185 & 154 \\
\hline Mean $(\mathrm{MPa})$ & 180 & 126 & 126 \\
\hline Std. Dev $(\mathrm{MPa})$ & 62.09 & 72.48 & 49.01 \\
\hline
\end{tabular}

The mean UCS of rock samples taken from each point obtained using Equation 8 is as follows:

$$
f=\frac{R}{300}+\sqrt{\frac{R}{30}}
$$

where $R$ is the uniaxial compressive strength $\left(\mathrm{kgf} / \mathrm{cm}^{3}\right), f$ is the resistance factor $\left(.1 \mathrm{kgf} / \mathrm{cm}^{3}=\right.$ $0.0981 \mathrm{MPa}$.

From Table 4, granite has the highest mean compressive strength at the Fobinso pit; and substituting this value, results in:

$$
\begin{aligned}
& f=\frac{1834.86}{300}+\sqrt{\frac{1834.86}{30}} \\
& f=13.94 \\
& f \cong 14
\end{aligned}
$$

With reference to Protodyakonov's classification of rock sturdiness, $\mathrm{f}=14$ confirms that the rock is granite, it falls in category II, it is very sturdy and requires fragmentation by blasting.

\subsection{Estimation of the Controllable Factors using Principle of Proportionality Parameters}

The first step is to relate the Rock Sturdy Index with the productivity of the pit; because, the rocks are of high resistance with $\mathrm{f}=14$ and production is mainly dependent on the conditions of the rock properties. The expected productivity, according to Table 7 , is $60 \mathrm{~m}^{3} / \mathrm{h}$ and the corresponding diameter is $65 \mathrm{~mm}$ for an open pit mine (Otaño, 2013). The hourly production of ore of the pit is $60 \mathrm{~m}^{3}$ and the rock strength is high, the diameter can be estimated as $65 \mathrm{~mm}$ according to Table 7 for open pits. The current drill diameter of $115 \mathrm{~mm}$ for Fobinso Pit is higher than the proposed $65 \mathrm{~mm}$.

The designed parameters using $65 \mathrm{~mm}$ for Konya and Walters, Principle of Proportionality and IGME are shown in Table 8 as KW-65, P-65 and IGME-65 respectively. Similar notations for 115 $\mathrm{mm}$ are shown in Table 9.
Table 7 Parameters for the Selection of Diameter of Drill

\begin{tabular}{|c|c|c|}
\hline \multicolumn{2}{|c|}{$\begin{array}{c}\text { Average Hourly Productivity } \\
\left(\mathbf{m}^{\mathbf{3}} / \mathbf{h r}\right)\end{array}$} & \multirow{2}{*}{$\begin{array}{c}\text { Diameter } \\
(\mathbf{m m})\end{array}$} \\
$\begin{array}{c}\text { Soft to } \\
\text { Medium } \\
\text { Strength }\end{array}$ & $\begin{array}{c}\text { Hard to Ultra- } \\
\text { hard }\end{array}$ & \\
\hline 190 & 60 & 65 \\
\hline 250 & 110 & 89 \\
\hline 550 & 270 & 150 \\
\hline
\end{tabular}

(Source: IGME, 1987)

However, when the diameter is reduced, the number of drillholes increases, causing the cost of drilling, priming and initiation increase. Stemming and connecting up operations are time consuming and labour intensive. Among all the three prediction models for $65 \mathrm{~mm}$ diameter, the principle of proportionality gave the least number of drill holes per row. However, IGME model gave the least charge per hole with the same powder factor as the Principle of Proportionality.

The determined blast parameters shown in Tables 8 and 9 were used to predict the fragmentation size distribution using the Modified Kuz-Ram model of $25 \mathrm{~ms}$ delay. Fig. 1 shows the predicted fragmentation size distribution for Konya and Walter (1990), Principle of Proportionality amd IGME parameters using the Modified Kuz-Ram.

The comparison of the prediction models using 115 mm with PMGL actual parameters are shown in Table 9. Larger diameters above the optimum can lead to poor fragmentation in highly fractures rocks with long spaced discontinuities. However, an increase in diameter is accompanied by an increased in charge diameter. Higher diameters increase explosion energy factor and higher detonation velocity. A stable and high detonation velocity produces good fragmentation (Hagan, 1983). A comparative analysis of the drill parameters in Table 9 reveal that the Principle of Proportionality gave the least drillholes of six per row. This means that Principle of Proportionality can help reduce drilling cost as compared to the drilling parameters currently in use in PGML. However, the charge per hole of PGML of $38.70 \mathrm{~kg}$ is lower than the $45.55 \mathrm{~kg}$ for the Principle of Proportionality design. 
Table 8 Comparison of Principle of Proportionality, Konya and Walter and PMGL Actual Parameters Using $65 \mathrm{~mm}$

\begin{tabular}{|l|c|c|c|c|}
\hline Designed Parameters & Symbol & KW-65 & P-65 mm & IGME-65 \\
\hline Burden $(\mathrm{m})$ & $\mathrm{B}$ & 1.86 & 2.36 & 2.15 \\
\hline Spacing $(\mathrm{m})$ & $\mathrm{S}$ & 2.26 & 2.59 & 2.47 \\
\hline Hole Depth $(\mathrm{m})$ & $\mathrm{H}_{\mathrm{d}}$ & 5.56 & 5.71 & 5.64 \\
\hline Sub-drill $(\mathrm{m})$ & $\mathrm{J}$ & 0.56 & 0.71 & 0.78 \\
\hline Stemming $(\mathrm{m})$ & $\mathrm{T}$ & 1.30 & 1.30 & 5 \\
\hline Bench Height $(\mathrm{m})$ & $\mathrm{H}$ & 5.0 & 5 & 4.47 \\
\hline Charge Length $(\mathrm{m})$ & $\mathrm{L}_{\mathrm{c}}$ & 4.25 & 3.78 & 1.20 \\
\hline Charge Density $\left(\mathrm{g} / \mathrm{cm}^{3}\right)$ & $\mathrm{A}$ & 1.20 & 1.20 & 12.98 \\
\hline Charge Per Hole $(\mathrm{kg})$ & $\mathrm{Q}$ & 16.93 & 14.55 & 0.68 \\
\hline Powder Factor $\left(\mathrm{kg} / \mathrm{m}^{3}\right)$ & $\mathrm{q}$ & 0.72 & 0.68 & 1.15 \\
\hline Spacing to Burden Ratio & $\mathrm{S}_{\mathrm{B}}$ & 1.21 & 1.1 & 2.33 \\
\hline Stiffness Ratio & $\mathrm{S}_{\mathrm{R}}$ & 2.68 & 2.12 & 25 \\
\hline Bench width $(\mathrm{m})$ & $\mathrm{B}_{\mathrm{w}}$ & 25 & 25 & 12 \\
\hline Number of rows & $\mathrm{N}_{\mathrm{R}}$ & 12 & 11 & 1.10 \\
\hline Distance b/n rows $(\mathrm{m})$ & $\mathrm{D}_{\mathrm{R}}$ & 0.93 & 1.16 & 5 \\
\hline
\end{tabular}

Table 9 Comparison of Principle of Proportionality, Konya and Walter and PMGL Actual Parameters Using $115 \mathrm{~mm}$

\begin{tabular}{|l|c|c|c|c|c|}
\hline Designed Parameters & Symbol & KW-115mm & P-115 mm & IGME-115 & PGML \\
\hline Burden $(\mathrm{m})$ & $\mathrm{B}$ & 3.30 & 4.17 & 3.80 & 3.1 \\
\hline Spacing $(\mathrm{m})$ & $\mathrm{S}$ & 3.51 & 4.59 & 4.37 & 3.5 \\
\hline Hole Depth $(\mathrm{m})$ & $\mathrm{H}_{\mathrm{d}}$ & 5.99 & 6.25 & 6.14 & 6.0 \\
\hline Sub-drill $(\mathrm{m})$ & $\mathrm{J}$ & 0.99 & 1.25 & 1.38 & 1.0 \\
\hline Stemming $(\mathrm{m})$ & $\mathrm{T}$ & 2.31 & 2.07 & 3.45 & 2.6 \\
\hline Bench Height $(\mathrm{m})$ & $\mathrm{H}$ & 5.0 & 5.0 & 5 & 5 \\
\hline Charge Length $(\mathrm{m})$ & $\mathrm{L}_{\mathrm{c}}$ & 3.68 & 4.18 & 4.07 & 3.4 \\
\hline Charge Density $\left(\mathrm{g} / \mathrm{cm}^{3}\right)$ & $\mathrm{A}$ & 1.20 & 1.20 & 1.20 & 1.20 \\
\hline Charge Per Hole $(\mathrm{kg})$ & $\mathrm{Q}$ & 45.86 & 45.55 & 3947 & 38.70 \\
\hline Powder Factor $\left(\mathrm{kg} / \mathrm{m}^{3}\right)$ & $\mathrm{q}$ & 0.66 & 0.68 & 0.68 & 0.59 \\
\hline Spacing to Burden Ratio & $\mathrm{S}_{\mathrm{B}}$ & 1.06 & 1.10 & 1.15 & 1.12 \\
\hline Stiffness Ratio & $\mathrm{S}_{\mathrm{R}}$ & 1.52 & 1.20 & 1.32 & 1.61 \\
\hline Bench width $(\mathrm{m})$ & $\mathrm{B}_{\mathrm{w}}$ & 25 & 25 & 25 & 25 \\
\hline Number of rows & $\mathrm{N}_{\mathrm{R}}$ & 8.0 & 6 & 8.0 & 8 \\
\hline Distance b/n rows $(\mathrm{m})$ & $\mathrm{D}_{\mathrm{R}}$ & 2.78 & 2.09 & 1.90 & 1.55 \\
\hline
\end{tabular}

\subsection{Fragmentation Prediction Using Modified Kuz-Ram Model}

All the prediction models produced similar size distribution patterns with more than $90 \%$ of the predicted sizes above the optimum size of $300 \mathrm{~mm}$. The predicted fragment size using IGME with drillhole diameter $65 \mathrm{~mm}$ had the least predicted percent oversize of about $0.2 \%$ with about $97.9 \%$ percent in range of $300 \mathrm{~mm}$. An analysis of the predicted size distributions curve in Fig 1 using $115 \mathrm{~mm}$ also revealed that (IGME model) had the least percent oversize of about $1.6 \%$ with about $96.6 \%$ within the optimum size range of $300 \mathrm{~mm}$. This can help us to deduce that IGME produced the best predicted fragmentation results for 65 and 115 $\mathrm{mm}$ for all the predicted models. About $93.2 \%$ of the predicted sizes of PGML were within the range of $300 \mathrm{~mm}$. This explains that the high percentage of boulders produced in the mine cannot be attributed to the current blast design but maybe due to poor operational practices by the drill and blast crew.

Ho: $\mu 1=\mu 2=\mu 3=\mu 4=\mu 5=\mu 6=\mu 7$ Null hypothesis (mean values have no significant difference)

H1: $\mu 1 \neq \mu 2 \neq \mu 3 \neq \mu 4 \neq \mu 5 \neq \mu 6 \neq \mu 7 \quad$ Alternate hypothesis (mean values have significant difference) 
The null hypothesis is valid when all the sample means are equal and can be considered as a part of a larger set. On the other hand, the alternate hypothesis is valid when at least one of the sample means is different from the rest of the sample means.

From the results in Tables 10 and 11 and, it can be seen that the F-value (0.031664) is lesser than the
F-critical value (2.157914) for the level of significant selected (0.05). Also, the p-value obtained (0.999862) from the analysis is greater than the selected p-value $(0.05)$. There is therefore not enough evidence to reject the null hypothesis and conclude that, the mean of the predicted values obtained using each prediction model has no significant difference for material size from 0.00 to 1100.

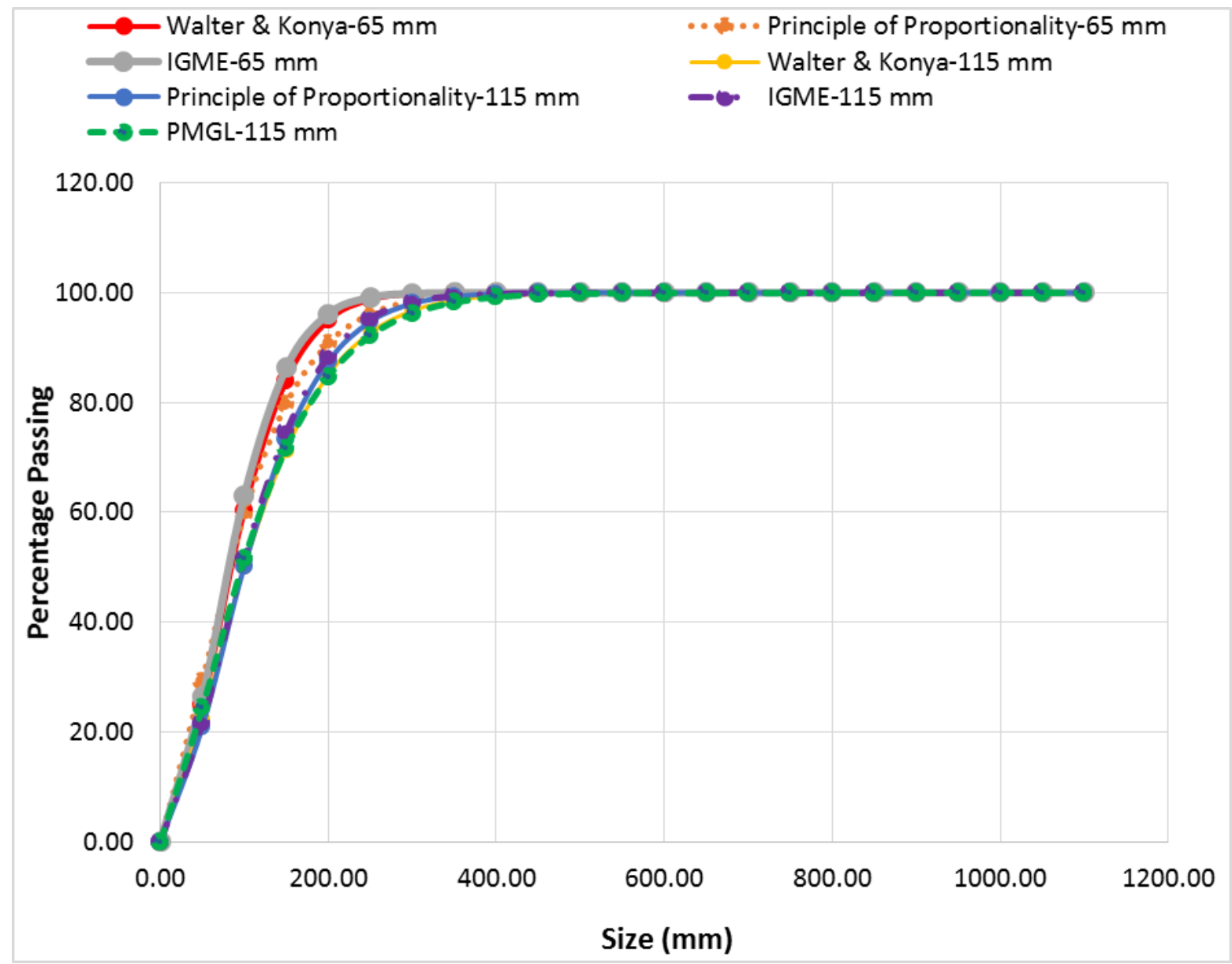

Fig.1 Predicted Size Distributions Curve

Table 10 Anova: Single Factor for $65 \mathrm{~mm}$ and $115 \mathrm{~mm}$

\begin{tabular}{lcccc}
\hline Groups & Count & Sum & Average & Variance \\
\hline Konya \& Walter-65 mm & 23 & 2016.276 & 87.66417 & 731.5854 \\
P.Prop.-65 mm & 23 & 2023.639 & 87.9843 & 741.5903 \\
IGME, -65 mm & 23 & 2029.055 & 88.2198 & 732.1177 \\
Konya \& Walter-115 mm & 23 & 2017.59 & 87.72129 & 714.5535 \\
P.Prop.-115 mm & 23 & 2062.393 & 89.66925 & 684.3943 \\
IGME, 1987-115 mm & 23 & 2053.324 & 89.27497 & 658.9134 \\
PMGL & 23 & 2070.881 & 90.03831 & 668.3651 \\
\hline
\end{tabular}


Table 11 Source of Variation

\begin{tabular}{lcccccc}
\hline Source of Variation & $\boldsymbol{S S}$ & $\boldsymbol{d f}$ & $\boldsymbol{M S}$ & $\boldsymbol{F}$ & $\boldsymbol{P}$-value & $\boldsymbol{F}$ crit \\
\hline Between Groups & 133.846 & 6 & 22.30767 & 0.031664 & 0.999862 & 2.157914 \\
Within Groups & 108493.4 & 154 & 704.5028 & & & \\
Total & $\mathbf{1 0 8 6 2 7 . 3}$ & $\mathbf{1 6 0}$ & & & & \\
\hline
\end{tabular}

\section{Conclusions}

The mean of the predicted values obtained using each prediction model has no significant difference for material size from $0.00 \mathrm{~mm}$ to $1100 \mathrm{~mm}$. The Principle of Proportionality model produced the least drilling cost. The prohibitive levels of boulders produced by the mine cannot be attributed to the existing blast design parameters. The boulders produced may be explained by inappropriate operational practices. All the predicted models produced fragment sizes of more than $93 \%$ within the range of the optimum size of $300 \mathrm{~mm}$ for the ore.

\section{References}

Bhandari, S. (1997), Engineering Rock Blasting Operations, A. A. Balkema Publishers, Rotterdam Brookfield, 139 pp.

Cunningham, C. V. B. (2005), "The Kuz-Ram Fragmentation Model - 20 Years on", Proceedings of the Brighton Conference, Modderfontein, South Africa, pp. $201-210$.

Frimpong-Mensah, C. (2016), "A Review of the Drilling and Blasting Practices at Goldfields Ghana Limited", Unpublished BSc Project Report, University of Mines and Technology, Tarkwa, $42 \mathrm{pp}$

Hagan, T. N (1983), "The influence of Controllable Fragmentation Parameters and Mining Cost, In First International Symposium on Rock Fragmentation by Blasting, Rustan, A. and Homberg, R. (eds.), Lulea, Sweden, August 2226, pp..31-52.

Konya, C. J. and Walter, E. J. (1990), Surface Blast Design, Prentice-Hall Inc., New Jersey, USA, $125 \mathrm{pp}$

Kuznetzov, V. M. (1973), “The Mean Diameter of the Fragments formed by Blasting of Rocks. Soviet Mining Science,9, pp.144-148.

Mensah, D. (2012), "Un Software Para El Diseno De Voladuras En Mineria a Cielo Abierto", Unpublished MSc Thesis Report, Escuela Tecnica Superior De Ingenieros De Minas, Madrid, Spain, 31 pp.

Mireku-Gyimah, D., and Boateng, S. K. (2018), "Selection of Blast Design for Kofi Pit C of Endeavour Mining Corporation, Mali”, Ghana Mining Journal, Vol.18., N0.2,pp. 30-36.

Mishra, A. (2009), "Design of Surface Blast - A Computational Approach", BSc Project Report,
National Institute of Technology, Rourkela, 77 pp.

Olofsson, S. O. (1988), Applied Explosives Technology for Construction and Mining, APPLEX, Arla, 304 pp.

Otaño, J. N. (1998), Fragmentacion de Rocas con Explosivos Editorial Felix Varela, La Habana, $446 \mathrm{pp}$.

\section{Authors}

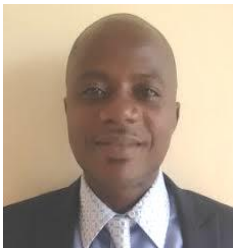

George Agyei is a Senior Lecturer currently working at the University of Mines and Technology, Tarkwa. He holds BSc and PhD degrees from Instituto Superior Minero Metalurgico de Moa,Cuba. He also holds an MBA from Educatis University, Altdorf, Switzerland. He is a member of Institute of Quarry, UK and WAIMM. His research and consultancy works cover Ore Beneficiation, Process Mineralogy, Sustainability and Mining.

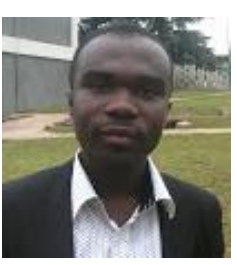

Michael Owusu-Tweneboah is an Assistant Lecturer in the Mining Engineering Department of the University of Mines and Technology (UMaT), currently pursuing his $\mathrm{PhD}$ in Mining Engineering. He holds BSc and MPhil in Mining Engineering from the University of Mines and Technology (UMaT). His areas of specialisation include Operations Research, Optimisation of Mining Systems, Modelling and Simulation of Mining Systems and Enrichment and Sustainable Environment. 